http://dx.doi.org/10.11646/zootaxa.3779.4.4

http://zoobank.org/urn:lsid:zoobank.org:pub:A5762089-AADF-41B6-B9E9-70C0371C30C2

\title{
A revision of the types of Neotropical Porricondylinae (Diptera: Cecidomyiidae)
}

\author{
MATHIAS JASCHHOF \\ Thälmann-Ring 64,D-17491 Greifswald, Germany.E-mail: mjaschhof@yahoo.de
}

\begin{abstract}
The type material of six species of Porricondylinae (Diptera: Cecidomyiidae) described from the Neotropical Region between 1905 and 1936 is re-examined. On the basis of revised adult descriptions the classification of these species is analyzed and discussed. Lectotypes are designated for Asynapta citrinae Felt, A. mangiferae Felt, Holoneurus occidentalis Felt, and Porricondyla gossypii Coquillett.
\end{abstract}

Key words: Diptera, Cecidomyiidae, Porricondylinae, Neotropical Region, type revision

\section{Introduction}

Porricondylinae, a fungivorous subfamily of the Cecidomyiidae (gall midges), are known to occur in all zoogeographic regions, yet their taxonomic diversity outside the Palearctic Region is little researched. Of 460 extant species known on earth, only six are described from the Neotropical realm (Gagné \& Jaschhof 2014). All six were found on islands and coastal states bordering the Caribbean Sea, a fact implying that the vast extent of the South American continent remains virtually a blank area for Porricondylinae. The small number of Porricondylinae known from the Neotropics is an artifact of research effort. To illustrate this fact, a three month survey of the Porricondylinae occurring in a small tract of Costa Rican cloud forest revealed more than 70 different species (Jaschhof, unpublished). So, while present-day research into porricondyline biodiversity could readily uncover hundreds of new species from the Neotropics, former dipterists left only a handful of described species to posterity. These are the subject of the present paper.

The six species in question were described between 1905 and 1936, four by Ephraim Porter Felt (1868-1943) and one each by Daniel William Coquillett (1856-1911) and Charles Paul Alexander (1889-1981). All three describers were North American entomologists specializing in Diptera, yet only Felt, who was State Entomologist of New York for 30 years, specialized in Cecidomyiidae. These particular porricondylines attracted the attention of science, because their larvae were found on cultivated plants of economic importance, such as mango or cotton. In another case it was the obviously exceptional morphology of the adult midge that led to a closer investigation.

Last to review the species treated here was Gagné (1994) in The gall midges of the Neotropical Region. Since then our knowledge of the Porricondylinae outside the Neotropics has markedly increased, so one can look at the same species in a different light today compared with 20 years ago. Even more time has passed since publication of the original descriptions, which makes it worthwhile to re-describe the type specimens, or what remains of them, from a modern perspective. Finally, there was a need to designate lectotypes for some of the species.

\section{Material and methods}

All type material of Neotropical Porricondylinae was loaned from the United States National Museum of Natural History (NMNH), Smithsonian Institution, Washington, DC. The holotype specimen of Felt's Camptomyia parrishi is actually under the ownership of the New York State Museum in Albany, New York, but belongs to Felt's slide collection that is on indefinite loan to the Systematic Entomology Laboratory of the U.S. Department of Agriculture, so available from the NMNH (see Gagné 2004). The material studied here consists of 12 microscope 
ventrad (Fig. 11). Female. Head. Antenna with 14 flagellomeres; circumfila consisting of two rings interconnected by two longitudinal threads; fourth flagellomere with short neck, node almost twice as long as wide. Terminalia. Ovipositor, beginning with segment VI, one third as long as abdomen, slightly protrusible. Tergite IX presumably not enlarged. Basicercus slightly longer than disticercus.

Classification. This species is not a Holoneurus in the current sense (see Jaschhof \& Jaschhof 2013) and even its tribal assignment-either to Dicerurini or Porricondylini-is somewhat problematic. The male shows porricondyline characters, such as the circumfila lacking posterior extensions and the parameres being tusk-shaped and discrete, whereas the female is dicerurine-like in that it has 14 flagellomeres and the ninth tergite not enlarged. The latter two female characters are regarded as synapomorphies of Porricondylini by Jaschhof and Jaschhof (2013). There is no reason to doubt that the male and female specimens in question are conspecific, so the character states found are in conflict with each other. All evidence considered, I assume that $H$. occidentalis is a Porricondylini and that the synapomorphies referred to above should be rated as underlying synapomorphies. As regards the generic assignment, I retain H. occidentalis in Holoneurus for the time being, as there is no other genus available that could absorb this species for any good reason; formally, this species is a Porricondylini incertae sedis. All indications are that $H$. occidentalis should be classified in a separate genus, which will become clear when its relatives are found and Porricondylini in the Neotropics are generally better known.

\section{Acknowledgements}

This study was performed during support from the U.S. National Science Foundation, grant DEB-1145890 to Dr. Brian V. Brown and Dr. Art Borkent. Dr. Raymond J. Gagné kindly initiated the loan of specimens from the NMNH collection. Dr. Gagné and Dr. Chris Borkent carefully read and commented on the manuscript.

\section{References}

Alexander, C.P. (1936) The maximum number of antennal segments in the order Diptera, with the description of a new genus of Cecidomyiidae. Bulletin of the Brooklyn Entomological Society, 31, 12-14.

Alexander, C.P. (1937) Change of name in Diptera. Bulletin of the Brooklyn Entomological Society, 32, 60.

Barnes, H.F. (1949) Gall Midges of Economic Importance. Vol. VI. Miscellaneous Crops. Crosby Lockwood \& Son Ltd., London, $229 \mathrm{pp}$.

Coquillett, D.W. (1905) A new cecidomyiid on cotton. The Canadian Entomologist, 37, 200. http://dx.doi.org/10.4039/ent37200-6

Felt, E.P. (1909) New species of West Indian Cecidomyiidae. Entomological News, 20, 299-302.

Felt, E.P. (1911) Three new gall midges (Dipt.). Journal of the New York Entomological Society, 19, 190-193.

Felt, E.P. (1915) New South American gall midges. Psyche, 22, 152-157. http://dx.doi.org/10.1155/1915/42393

Felt, E.P. (1932) A new citrus cambium miner from Puerto Rico. Journal of the Department of Agriculture of Puerto Rico, 16, $117-118$.

Gagné, R.J. (1981) Cecidomyiidae. In: McAlpine, J.F., Peterson, B.V., Shewell, G.E., Teskey, H.J., Vockeroth, J.R. \& Wood, D.M. (Coordinators), Manual of Nearctic Diptera. Vol. 1. Research Branch, Agriculture Canada, Ontario, Monograph No. 27, pp. 257-292.

Gagné, R.J. (1994) The gall midges of the Neotropical Region. Cornell University Press, Ithaca, New York, 352 pp.

Gagné, R.J. (2004) A Catalog of the Cecidomyiidae (Diptera) of the World. 1st Edition. Memoirs of the Entomological Society of Washington 25, $408 \mathrm{pp}$.

Gagné, R.J. \& Jaschhof, M. (2014) A Catalog of the Cecidomyiidae (Diptera) of the World. 3rd Edition. Digital version 2. Available from: http://www.ars.usda.gov/SP2UserFiles/Place/12454900/Gagne_2014_World_Cecidomyiidae_Catalog_3rd_Edition.pdf (accessed 26 February 2014)

Jaschhof, M. \& Jaschhof, C. (2009) The Wood Midges (Diptera: Cecidomyiidae: Lestremiinae) of Fennoscandia and Denmark. Studia dipterologica Supplement, 18, 1-333.

Jaschhof, M. \& Jaschhof, C. (2013) The Porricondylinae (Diptera: Cecidomyiidae) of Sweden, with notes on extralimital species. Studia dipterologica Supplement, 20, 1-392.

Jiang, Y.-X. \& Bu, W.-J. (2004) A newly recorded gall midge genus (Diptera, Cecidomyiidae) with a species, Asynapta groverae Jiang et Bu, nom. nov. from China. Acta Zootaxonomica Sinica, 29, 786-789.

Mamaev, B.M. \& Zaitzev, A.I. (1997) New genus and species of free-developing gall midges of the subfamily Porricondylinae from Somalia (Diptera, Cecidomyiidae). Journal of the Ukrainian Entomological Society, 3 (2), 5-13. 